\title{
Gender Issues in Cooperative Societies of Ilam
}

\author{
Bhupal Krishna Thapa \\ PhD Scholar \\ Dr. K. N. Modi University, Newai, Rajasthan, India \\ bhupalkthapa@yahoo.com
}

\begin{abstract}
Cooperative is an organization run by the similar professional people for the betterment of their socio-economic uplift with common goals in the democratic way. The success or failure of any cooperative depends upon the members' role. If the female memberships are grown, and opportunities are given in governance, cooperative societies will be successful. The present study was conducted to explore the status of cooperative female members' memberships, and governance like board of directors and job opportunities provided by the concern cooperatives in Ilam, Nepal. The nature of the study was quantitative and qualitative implying survey method and in-depth interview. There were 226 cooperative members from three types of cooperatives: Savings and Credit, Tea, and Dairy cooperatives. The present study showed that the majority of the female members were deprived of their basic rights of participating in AGM, board of directors and office works from their concern cooperatives. Thus, the cooperatives are requested to encourage their female members in memberships, and governance.
\end{abstract}

\section{KEY WORDS}

Cooperative, governance, membership, policy

\section{INTRODUCTION}

Co-operatives are based on the values of self-help, self-responsibility, democracy, equality, equity and solidarity. In the tradition of their founders, co-operative members believe in the ethical values of honesty, openness, social responsibility and caring for others (Alliance, 1995). Similarly, Craig (1993) defines cooperative is the free and voluntary association of people to create an organization which they democratically control, providing themselves with goods, services and/or a livelihood rather than profiting from others, with an equitable contribution of capital and acceptance of a fair share of risks and benefits generation by the joint activity. To sustain their endeavor they must develop individuals and build a solidarity relationship with other co-operators and like-minded people (p. 43).

While talking about equality and equity, gender roles play vital role on the development of cooperative societies. Gender refers to the socially constructed roles, behaviours, activities, and attributes that a given society considers appropriate for men and women. Gender concept simply refers to the socially strong-minded and culturally specific differences between women and men as divergent to the biological determined differences. Gender imbalance in employment, in job status, in poverty status and in earnings over time constitutes the major 
problems affecting the development of cooperative industries. To increase female participation in cooperatives, policy of it plays important roles.

"A policy is a statement that provides guidelines for actions to attain the established objectives of the cooperative and reflect the cooperative's basic philosophy" (Rapp, 1990, p. 1). Policies are directions to plans. Well written policy facilitates delegation of authority to the lowest realistic level in the cooperative. Written policy statements are supposed to be a major factor of each cooperative's planning activity. So that, these policies reflect the cooperative's basic philosophy and assist as guidelines for actions the cooperative takes to achieve its established objectives. Rapp (1990) states that policies are not all of equal importance. Some policies are of such significance they determine the character of the business. Others are limited in scope and could be changed or eliminated without effect. The International Cooperative Alliance (ICA, 2010) defines a cooperative as "an autonomous association of persons united voluntarily to meet their common economic, social, and cultural needs and aspirations through a jointly-owned and democratically-controlled enterprise" (ICA, 2010).

The definition of the co-operative focuses on the members' participation. To be perfectly participated in the co-operative female members should be encouraged in memberships and governance. Governance means board of directors or/and working staffs. Merely the written policy cannot perform the output unless it is implied perfectly. The success or failure of the policy depends upon its practice. Thus, the present study aimed to explore the status of female members' participation in annual general meeting (AGM), board of directors and job in the cooperatives.

\section{METHODO}

\section{Design and Participants}

The study was explorative in design employing a survey and in-depth interview. Within the survey, a set of questionnaire measured status of the co-operative members' participation in last AGM, board of directors and job. There were 226 respondents. Among them, 89 members of Savings and Credit Cooperatives, 40 from Tea Cooperatives and 97 of Dairy Cooperatives from Ilam district of Nepal. There were 153 male and 73 female respondents.

\section{Materials}

The construct was measured using survey questionnaires as well as semi-structured interview questionnaire. The initial instructions to participants were presented on the first page of the survey and included safe practice question in the style common to most survey items.

\section{Procedure}

For the quantitative data, the questionnaire was designed in different layers to its perfectness. In addition, final draft versions of the questionnaire was shown to a small number of co-operative members known to the researcher as a means of gaining an initial evaluation of the survey's readability and of the likely time required for completion. The trial 
questionnaire was not subsequently used for any other purpose and was destroyed. The researcher then outlined the study and its objectives, after which it was collaboratively decided how to best implement the research process. Consequently, the participant Information Sheet was later distributed. Completed surveys were collected by the researcher and sealed in unmarked envelopes. For the qualitative data, the researcher prepared a semistructured questionnaire of interview and visited exports of cooperatives. It was recorded in a tape, later on transcribed into checklists.

\section{RESULT AND DISCUSSION}

\section{Types of cooperatives and gender of respondents}

Table 1 Gender * Type of Cooperative Crosstabulation

\begin{tabular}{|l|l|l|l|l|l|}
\hline & \multicolumn{2}{|l|}{ Type of Cooperative } & \\
\hline \multirow{4}{*}{ Gender } & & $\begin{array}{l}\text { Savings and Credit } \\
\text { Cooperative }\end{array}$ & $\begin{array}{l}\text { Tea } \\
\text { Cooperative }\end{array}$ & $\begin{array}{l}\text { Dairy } \\
\text { Cooperative }\end{array}$ & Total \\
\cline { 2 - 5 } & Male & 43 & 29 & 81 & 153 \\
\hline Female & 46 & 11 & 16 & 73 \\
\hline Total & 89 & 40 & 97 & 226 \\
\hline
\end{tabular}

Source: Field survey 2015

The result shows that there is gender discrimination on members' participation in cooperatives. It fails the internationally accepted cooperative values and principles of equality and equity. The ILO Work Series (ILO, 2014) states as:

The internationally agreed Cooperative Values and Principles commit the cooperative movement to the values of self-help, self-responsibility, democracy, equality, equity and solidarity. Democratic member control based on one member one vote and without gender, social, racial, political or religious discrimination lies at the heart of cooperative values. (p. 1)

In one hand, gender disparity in leadership, education, management and employment seems to lower the economic growth of our societies. Although cooperative organizations and governments have policies of equity and equal opportunity, cooperative societies will confirm that women are afforded equal treatment concerning employment opportunities, promotion, etc. Democratic participation in cooperatives means that men, women and youths should participate equally in cooperatives and that both men's, women's and youths' needs and concerns must be addressed equally.

On the other hand, technical inefficiency is due to inadequate working capital for the co-operators, lack of education, poor management, and low level of participation among members mainly the male co-operators, lack of extension education and service, wrong timing of meetings, conflicting interest, gender inequality, and long distance to meeting venues.

In the context of Nepal, still the women are made busy in the household works. Only men take initiations in outdoor works and other activities. Similarly, women are less aware 
about rights and duties that they have to utilize. In this context, cooperative societies have to bring series of programs to aware women about outdoor activities and income generation works.

\section{Gender and members of board of directors in cooperative societies}

Through the research survey, data of the representation of male and female in board of directors were collected. The following table shows the result.

Table 2: Male and female directors

\begin{tabular}{|c|c|c|c|c|}
\hline No of directors & $\begin{array}{c}\text { No of } \\
\text { cooperatives } \\
\text { (male) }\end{array}$ & $\begin{array}{c}\text { No of } \\
\text { cooperatives } \\
\text { (female) }\end{array}$ & Male Total & Female Total \\
\hline 1 & 0 & 7 & 0 & 7 \\
\hline 2 & 0 & 5 & 0 & 10 \\
\hline 3 & 0 & 7 & 0 & 21 \\
\hline 4 & 0 & 2 & 0 & 8 \\
\hline 5 & 2 & 1 & 10 & 5 \\
\hline 6 & 5 & 0 & 30 & 0 \\
\hline 7 & 3 & 0 & 21 & 0 \\
\hline 8 & 8 & 0 & 64 & 0 \\
\hline 9 & 3 & 0 & 27 & 0 \\
\hline 10 & 1 & 0 & 10 & 0 \\
\hline Total & 22 & 22 & 162 & 51 \\
\hline
\end{tabular}

Source: Field survey 2015

The results show that out of 22 cooperatives, in 7 there are only one female director in each, in 5 cooperatives 2 each, in 7 cooperatives 3 each, in 2 cooperatives 4 each and in 1 cooperative 5 directors. In total, out of 213 members 51(23.94\%) female members were getting chance in board of directors. On the other hand, $162(76.04 \%)$ male members were holding the leadership. It shows too much gap of gender in leadership. Gender inequality directly or indirectly limits the economic growth. It should be decreased from policy level.

In an interview, K.B. Upreti, Managing director of National Cooperative Bank, Nepal, suggested on making sure of gender equality on cooperatives as:

The law and regulations should be appropriate to the equal participation of both sexes. Access to the benefits of the cooperative must ensure to all in a democratic manner. The cooperatives must be open and ready for training and education geared toward the needs of women. Participation in the management of the cooperative like Board of Directors, Auditing Council, Committees, etc. should be balanced between women and men.

He further suggests that extension education and service should be intensified to ensure that the capacity of the experienced farmers and co-operators are enhanced for greater productivity. Intensified sensitization programme should be undertaken, with a view to 
inspiring participation in cooperative activities among existing and potential male cooperators. This is necessary because of the declining participation of male co-operators in cooperative activities and the increasing problem of gender imbalance therein. In cooperative sector, it is relevant to analyse the role and position of men and women in their socioeconomic environment in order to identify and address their different needs, develop their strengths and capacities and to ensure a reasonable distribution of the benefits of cooperative development in Nepal.

\section{Gender and presence of members in AGM}

We live in a world where, without any doubt, the social, political, economic power are owned by men. Almost all the societies are more or less male-controlled and the gender roles are, commonly speaking, well defined and assumed by the representatives of each gender. Attaining equality of opportunity between men and women is a long process and cooperatives in all parts of the world still have a long way to go before they are able to claim that they are truly gender reactive. However, the very fact that cooperatives, as opposed to other types of enterprise, have to pay attention to the needs and interests of their members, gives them a distinct role to play. Members, clients and customers very often perceive cooperatives as having a high regard for business ethics, therein-included equality issues, so in order to attract new members and loyal clients and customers, cooperatives should take benefit of this.

To assess the gender role in the development of cooperatives data were taken through questionnaire survey. To sample their representation in the cooperatives, the following result shows presence of male and female in the AGM of concerned cooperatives.

Table 3 : No of male and female participants in AGM

\begin{tabular}{|l|l|l|}
\hline & N & Sum \\
\hline No of male participants present in last AGM & 22 & 2536.00 \\
\hline No of female participants present in last AGM & 22 & 1406.00 \\
\hline Valid N (listwise) & 22 & 3942.00 \\
\hline
\end{tabular}

Source: Field survey 2015

The data were taken from 22 cooperatives societies. Out of 3942 members who were present in the AGM, 2536 (64.33\%) were male and 1406 (35.67\%) were female. It shows distinct gap between male and female presence.

Many cooperative businesses today have obviously formulated policies on equal chances but practice may, of course, differ. Very few cooperatives, for example, actually have a percentage of women in decision-making positions that corresponds to the percentage of women in the membership. A key starting point is therefore to ensure that cooperative leaders and management are clarified to gender issues. It is only with a understanding of the issues and a commitment to systematically address them that proactive measures will be taken by the leaders and managers. Ensuring that gender concerns are mainstreamed in all cooperative policies, legislation, mission statements, visions, by-laws, strategies, plans and programmes is also essential. 
Although cooperative societies and government have gender equality policies, cooperatives have to ensure female membership and economical generation. Unless female participation is not encouraged, it is difficult to enhance overall development.

\section{Gender difference in job opportunities}

Both male and female have equal rights on employment. However, gender imbalance in employment, in job status, and in earnings over time constitutes the major problems affecting the development of cooperative industries. The following results show the imbalance of job opportunities between male and female.

Table 4: Number of male and female employs

\begin{tabular}{|c|c|c|c|}
\hline & N & Sum & $\%$ \\
\hline No of male employs & 22 & 62.00 & 82.67 \\
\hline No of female employs & 22 & 13.00 & 17.33 \\
\hline Valid N (listwise) & 22 & 75.00 & 100 \\
\hline
\end{tabular}

Source: Field survey 2015

The researcher collected data of employs from 22 cooperative societies. Out of 75 employs, $62(82.67 \%)$ were male and only $13(17.33 \%)$ were female. It shows a big gap between male and female job opportunities.

This was an indication that within the sample cooperative societies the workforce had more male employees than female. This difference between male and female employees could indicate a lesser level of participation of females than male in cooperative matters or in formal employment. Further, the one-third gender rule advocated for and lately entrenched in the Nepalese constitution is apparently yet to take toll.

K.B. Upreti, General Manager of National Cooperative Bank Nepal, has strongly recommends that there must have promotion of the basic principles of cooperatives. Similarly, there should be encouraging the professionalization of women in the activities of the cooperatives. We should encourage the promotion and empowerment of cooperativist women. Furthermore, there must be strengthening the development of public policies for gender equality, and promoting partnerships.

\section{CONCLUSION}

The study explored that cooperatives in Ilam neither are nor gender friendly. There is a big gap of participation in cooperatives between male and female members. For the success of any cooperative role of members is very important. Thus, the study suggested that there is a need for monitoring and counselling programs that promote to gender equality. In terms of further research, the study recommended that a similar study be undertaken in other areas of Nepal so that the study is representative of the whole country. 


\section{REFERENCES}

Alliance, I. C.-O. (1995). Centennial Congress of the International Co-operative Alliance, Man International Co-operative Alliance. Retrieved from The ICA Statement on the Co-operative Identity: http:// www.coop.org/ica/

Bhowmik, S. K. (1997, September 27 - October 3). Participation and Control: Study of a Cooperative Tea Factory in the Nilgris. 32, 106-113. Economic and Political Weekly.

Craig, J. (1993). The Nature of Co-operation. Montreal, Quebec: Black Rose Books.

Dahal, K. P. (2012). Present Status and Business Destination of Cooperative. Sahakari Sambad, pp. 28-34.

ICA. (2010).

ILO. (2014). Leveraging the cooperative advantage for women's empowerment and gender equality. Retrieved June 19, 2016, from COOPERATIVES AND THE WORLD OF WORK No.1: http://www.ilo.org/wcmsp5/groups/public/---ed_emp/---emp_ent/--coop/documents/publication/wcms_307217.pdf

MacPherson, I. (1996). Co-operatives Principles for the 21st Century. International Cooperative Alliance.

Rapp, G. (1990). Sample Policies for Cooperatives. United States Department of Agriculture.

Thakuri, C. B. (2011). Management of Co-operative Business in Nepal: Priciples and Practices (3rd ed.). Kathmandu, Nepal: Upakar Publication. 